\title{
An Exploratory Study on the Practice of Pagsasanto by Openly-Gay Santeros
}

\author{
Samuel Brando H. Piamonte, ${ }_{1}^{1}$ Mark Anthony M. Quintos, ${ }^{2}$ and Minami O. Iwayama ${ }^{3,4}$ \\ ${ }^{1}$ Philippine Council for Health Research and Development, Taguig City, Philippines \\ ${ }^{2}$ De La Salle University, Malate, Manila, Philippines \\ ${ }^{3}$ Polytechnic University of the Philippines, Manila, Philippines \\ ${ }^{4}$ Ateneo de Manila University, Quezon City, Philippines
}

\begin{tabular}{l} 
Article history: \\
Submitted: 31 October 2020 \\
Revised: 21 December 2020 \\
Accepted: 31 December 2020 \\
\hline Keywords: \\
Religious images \\
Gay men \\
Santero \\
Qualitative research \\
Philippines
\end{tabular}

ABSTRACT. This exploratory study was conducted to inquire into the experiences of gay santeros - those who take care of religious statues or imahes that are used for Catholic religious activities. The study looked into the entry of the santeros to the practice of pagsasanto, their access to the imahe, their reasons for entering and maintaining the practice, and the benefits that they perceive to derive from it. Through conducting interviews with openly-gay santeros, it was found that early exposure to their religious family, school, and local community influenced them into entering the practice of pagsasanto. On access to the imahe, the participants were either owners of the imahe through purchase, donation or inheritance, or caretakers of the imahe through entrustment by their religious networks. On reasons for entering and maintaining the practice, it was found that such was conducted and maintained for egoistic reasons, self-expression, legacy, or spirituality. Lastly, it was found that advantages on health and subsistence, personal development, and social rewards were the perceived derived benefits from the practice of pagsasanto. These findings suggest implications pertaining to the dynamics of religiosity and non-normative gender identity in the Philippines where the Church finds willing caretakers among gay Catholics while gays find an avenue for expression of gender identity and creativity in the task given to them.

\subsection{Introduction}

Religious images are an important part of the religious lives of Filipinos. In the pre-Hispanic Philippines, ancient Filipinos kept in their altars images representing household deities, deceased ancestors, nature-spirits, among others, to represent the anito or the spirit to which they sought guidance and protection. During the 1500s, Magellan erected a cross to symbolize the Spaniards' success of introducing Christianity to the Philippines through the conversion of Rajah Humabon, his wife, and his 800 other subjects (Bernard, 2002). Along with the symbolic cross came the Santo Nino, which was gifted by Magellan to Rajah Humabon's wife. When Magellan died, and the remaining crew returned to Spain, the natives returned to their old beliefs. They made the image into a pagan idol (Caulin, 2017). Years later, while Miguel Lopez de Legazpi was raiding villages, they saw the Santo Nino again underneath the fires, to where Legazpi ordered a shrine be built (Caulin, 2017). At present, the Santo Niño is deemed one of the most important religious images in the Philippines. It symbolizes Catholicism in the Philippines. However, aside from the Santo Nino, Filipino Catholics have many other religious images. These are often exhibited during religious festivities such as fiestas, Mahal na Araw, Santacruzan, and Christmas, among others. In such events, the handler of such religious images are oftentimes gay santeros.

Pagsasanto in this paper pertains to the acts of maintaining the religious images or Imahe or Poon or Santo, preparing it for religious activities, and fielding it during processions. On the other hand, a Santero (or camarero) in this paper is defined as an individual who serves as a caretaker of the image. The available literature on this practice in the Philippines includes the social class aspects of pagsasanto in the rural Philippines (Venida, 1996), use of ivory in the creation of an ecclesiastical statue (Martin et al., 2011), and the sponsorship of religious images in Cabiao, Nueva Ecija (Galang, 2012) which was extended by Tamayo (2020) who examined contemporary sponsorship systems. Others focus on theatrical dance in the community-based celebrations of Santo Niño during the Ati-Atihan Festival (Peterson, 2011) and the Our Lady of Peñafrancia during the Peñafrancia festival (Peterson, 2020). The various images of Christ significant in the Filipino culture has also been documented theologically by Delotavo (2001).

What is noteworthy about the individual Filipino santeros is that there is a large proportion of people who are gay. In this sense, the reality of pagsasanto is one wherein many of its members identify themselves as part of an identity often viewed as deviant by the very religion where they 
served as caretakers of the religious images. Despite this seeming contradiction, it is curious that openly gay members of the Filipino religious community continue to engage themselves in practice - a question not yet been extensively answered by existing local literatures.

In this study, openly-gay santeros refer to caretakers of religious images who identify as gay. What this exploratory research did was to venture into an inquiry on the experiences of these openly gay santeros. In particular, this research aimed to answer how the gay santeros gained access to the imahe under their care, their reasons for the engagement in practice, and the benefits they perceive to derive from pagsasanto.

\subsection{Methods}

The research questions necessitate the use of a micro-sociological level of analysis since the study objectives do not focus on large scale structures but rather on individuals and their interpersonal connections within the context of their everyday lives. Thus, the warranted methodological orientation is qualitative, where research becomes interpretative and naturalistic (Creswell, 2013). Through a qualitative approach, researchers understand how individuals learn and make sense of themselves and give meaning to their lives (Berg, 2001).

Two criteria were enforced in the choice of participants: (1) they must be openly-gay and (2) they must be a santero who serves either as owner or steward of at least one Santo/imahe commonly featured in Roman Catholic Lenten processions. Five participants were engaged in interviews for the study.Five participants were deemed enough for the exploratory nature of the study and in consideration of the resources under the disposal of the research team. All five participants have been santeros for more than five years. Four of the participants were personally known by one of the authors. At the same time, the fifth participant was referred by one of the participants. All of them consented to the interview after being briefed about the nature and objectives of the study. The name and other identifiers of the participant santeros were omitted in this report to protect their privacy. In-depth interviews were led by the main author. This was deemed best because he is also an active santero, making access and establishing rapport relatively easier for the researchers. Only five santeros took part in the study as the time and resources of the researchers were of consideration aside from the exploratory nature of the study. All interviews were audio-recorded with permission from the participants and were subsequently transcribed and analyzed. Thematic analysis was performed to unearth themes emanating from their narratives. Findings were conveyed to selected participants for validation. They have consequently concurred with the study results.

\subsection{Results}

The goal of the paper is to explore the experiences of openly-gay santeros. To facilitate the discussion, this section has been divided into the entry of the santero participants to the santero life, the reasons for engagement, and the santeros' perceived benefits from owning an imahe.

\section{Entry to pagsasanto}

Understanding the santero phenomenon requires an exploration of how its participants learned about the tradition, how they could take part in it, and why they gained access to the imahe. A unifying theme in the stories of the participants is their early exposure to the life of Pagsasanto early on in their life. This early socialization into the santero life is facilitated by the following agents of socialization in society:

Family. The first agent of socialization into the Santero life is the family, where the religious practices of their families were contributory to the start of their fascination with taking the case of imahes. "Bata pa lang ako, naaalala ko tuwing Holy Week nagpapabasa sa bahay at doon sa simbahan. Tapos yung tito ko, siya yung nag-aalaga ng patron ng simbahan namin. So ayun, siya nagbibihis tapos nakikita ko. Sabi ko, Ay! Gusto ko rin nun!", (I remember when I was a child that during Holy Week, we have pabasa in our house and in the church. My uncle also takes care of the patron saint of our church. He changes the vestments of the saint and I told myseld "Oh! I want that too!), or the participants' families are santeros themselves and, therefore, taking care of religious images is a collective family tradition that they grew up in. As one of the participants put it:

"Since bata pa ako, yung family namin, religious na. Lagi kaming active sa simbahan.

Meron din kaming mga imahe na ilaagaan." (I remember that when I was a child, there 
was Pabasa in our homes and the church during Holy week. My uncle takes care of our churche's patron image. I see him change the vestments of the image and told myself "Oh! I want to do that too!")

School. The second agent of socialization into the Santero life is the school institution. The sectarian schools to which the participants were enrolled in exposing them to activities related to religious devotion, which became a normal part of their life:

"Kasi laking Catholic school ako. Ikaw ba naman, simula kindergarten hanggang fourth year high school... may religious activities." (I grew up in a Catholic school. From kindergarten up to fourth year high school, we have religious activities.)

One of the participants decided to become a santero during his high school days and immediately became one upon graduating:

"Nung high school ako, nagustuhan ko rin na magkaroon ng sarili kong imahe... before ako grumaduate ng high school, nagdemand ako na talagang gusto ko nang magkaroon ng sarili ko talagang imahe. So surprise, ayun, ginulat nila ako na naipagawa nila ako ng Cleofe." (When I was a high school student, I wanted to have my own religious image. Before finishing high school, I demanded to have one. I was surprised an image of Sta. Maria Cleofe was made for me.)

Community. The local communities to which the participants are residing further reinforced their exposure to pagsasantero. The participants live in areas with a predominantly Roman Catholic population and a long-standing tradition of making grand gestures of observing Catholic celebrations. As one of the participants explained,

"Kasi mula pagkabata ko, talagang si Don Escudero ang pinaka-standard kasi maganda talaga mga imahe niya. Wala pa akong alam sa mga ivory-ivory, ganyan. Basta alam ko, imahe, tapos kailangan, maganda ang damit, maganda ang karo, maganda ang pukpok, lahat yun." (Since childhood, Don Escudero is the standard because his images are beautiful. I did not even know what ivories were. All I know is that images should have beautiful vestments and carrozas.)

\section{Requisites for pagsasanto}

The importance of family, school, and community as agents influencing the lives of the santero participants is pronounced further in their stories of how they could gain access to their respective imahes. Two ways of the mode of acquisition are presented in this paper. Participants either gained access to the imahe by owning one or being entrusted to care for an Imahe by their religious network.

The first way to gain access to an imahe is by owning one. Owning an Imahe can further be classified into the following: [1] Owning by Purchase, [2] Owning by Inheritance, and [3] Owning by Donation. The most challenging mode of personal ownership seems to be ownership by purchase because the imahes are expensive pieces of art that require a certain degree of preparation for most santeros before they can manage to purchase one. The imahes are commissioned by wouldbe santeros from woodcarvers, often from Paete, Laguna - known as the Carving Capital of the Philippines under Proclamation No. 809, s. 2005. Benefits of ownership by purchase include exercising a degree of freedom in choosing what imaheto take care of. The choice of an imahe to be commissioned is reported by the participants to be influenced by the following considerations -1 ) the santero can choose a saint who is not yet owned by another santero in the community to avoid duplication (which they deem aversive because duplication lessens opportunities for participation in religious processions), 2) the santero can also choose to commission the production of the imahe that he finds most meaningful or important, and 3) the santero can choose what saint they can dress-up and present with consideration to their creative preferences and available resources. A santero may also gain access to an imahe through ownership by donation or when the imahe is gifted to them. Also, the Santero takes care of the imahe (i.e., as a caretaker) while often older relatives or friends still retains ownership. The Santero then eventually inherits the imahe when its original owner passes away or can no longer take a major part in the care of the imahe.

The second way santeros gain access to an imahe is when it is entrusted to them by a member of their religious network. These religious networks may come in two forms: private religious networks or the Roman Catholic Church itself. 
Regardless of the mode of access to the imahe, our santero participants agreed that taking care of an imahe have certain requisites which, while informal, are perceived by the participants to be necessary "sacrifices" to properly perform the devotion of pagsasanto, namely:

Financial resources. Our santero participants unanimously agreed that money is a major requisite in pagsasanto, making it somewhat of a selective form of devotion that is open predominantly to those with sufficient economic power. As one of the participants put it: "Kung wala kang pera, wala kang pambili ng bulaklak, pangrenta ng karo, pang generator, gasonila, bayad sa taong maghihila, pakain sa mga tutulong. Kailangan mo ng pera, number one yun." (If you don't have money, you can't buy flowers, rent a carroza, generator, and gas, pay people who will pull the carroza, and buy food for the individuals who till help. You need money and that's number one.) It bears noting that there is no specific instruction from the Church stating that taking the imahe should entail substantial financial sacrifices. However, the santeros take it upon themselves to give the best that their resources can afford, most likely as a symbol of their devotion:

"Syempre kung kaya ng financials mo na ibigay yung pinakamagagandang gamit... bakit hindi mo ibibigay?" (Of course, if you have the financial capacity to give the best vestments, then why deprive your image of these?)

This salience of the financial burden in pagsasanto led one of the participants to give the following advice to would-be santeros:

"Advice lang. Wag kayong magsasanto kapag alam niyo sa sarili niyo na wala pa kayong capacity... Kasi there are so many... as young as 12 years old na gustong magka-imahe. Yet, they are not thinking of their... financial status... unlike ako kasi maswerte ako my family is capable... hindi naman lahat ganun. In the long run, they have to think of their... financial status kasi having an imahe is not an easy job. It takes a lot of money, time, and effort." (Just an advise, you cannot be a Santero if you know you do not have the capacity. As young as 12 years old, there are a lot who want to acquire an image, yet they do not think of their financial status. Unlike me, I am lucky that my family is capable of. In the long run, they have to think of their financial status because having an image is not an easy job.)

As a way to cope with the financial weight of pagsasanto, some of the participants ask for donations from other devotees, emphasizing once more the value of a strong religious network:

"Nagso-solicit ako, pero hindi naman para sa lahat ng gastos. May part na akin, pero karamihan, hingi sa mga friends." (I solicit a portion of the needed costs where part of the costs come from me while others are solicited from friends.)

Patience. Aside from financial resources, the importance of patience in the form of time and effort is also stated as a requisite of being a santero. According to one participant:

"Time and effort. Syempre... kailangan mo ng mahabang oras kasi mag-iinvest ka rin ng pera, magtatrabaho ka para mabuo mo yan. Hindi naman kaya ng marami na mabuo biglaan. Yung sa effort, pag andyan na at nabuo na, as in talagang kumakain ng oras para ayusan, bihisan, ipanhik sa karosa, kailangan mo lahat pati generator, paglinis ng karo, paglabas ng hawakan, unless meron kang mga tao. Pero iba pa rin talaga yung hands-on ka talaga sa imahe mo eh. Iba pa rin yung feeling." (Of course, you need time and money. You have to work to own an image. In terms of effort, when the image has been finished, it takes time to dress it up and arrange it on the carroza. You also need a generator. You also need to clean the carroza.)

\section{Reasons for entering and continuing the practice}

The reasons why they started the practice were also inquired. The study found that these reasons range from mundane to spiritual. Our interviews showed that the santero participants engage in the conduct of pagsasanto for egoistic reasons, self-expression, legacy, and/or spirituality.

Egoistic reasons. One reason for entering the practice is due to egoistic reasons. In this sense, pagsasanto served as a symbolic gesture of personal accomplishment.

"At first, it was for my ego. Kasi inisip ko nung nagkaroon ako ng Imahe at the age of 15 na, ah, ako ang nauna... sa lugar ko. Kumbaga, that is a great achievement for me. Noon kasi, I think of it as bragging rights kasi bata pa lang eh may Imahe na ako". (At first, it was for my ego because I thought having an imahe at the age of 15 makes me the first to have one in 
my community. It is like a great achievement for me. Before, I thought of having an imahe at the age of 15 is a bragging right.)

This is further made salient when it was explained that they, and some of the fellow Santeros that they know, started with the practice because it was the trend among gays during their time. However, these motivations were generally at the initial stage of pagsasanto. The reason for continuing the devotion changes over time.

Self-expression. The imahe is reportedly being treated like a doll, or a "Barbie doll" as often called in the Philippines by the gay santeros. As explained by one participant, there is a reason why the individual santero members are predominantly comprised of gays:

"Aminin na natin na halos lahat ng mga santero, ginagawang Barbie kasi gusto nilang i-express yung pagigiging bakla nila, dahil hindi sila makapagsuot ng pambabae, sa imahe nalang ine-express yung gusto nila. Pero sa pag-eexpress ng art na gusto nila sa imahe, mayroon pa rin namang debosyon." (Let us face it. Almost all of the santeros make their images Barbie dolls because they want to express their gayness and not wear feminine clothes. They express what they want through the images but in that expression comes devotion.)

The appeal of pagsasanto to gays as a venue to express their creativity and interest in playing dress-up with dolls without fear of ostracism from society is further made salient when it was explained that, due to this particular motivation, even non-believers engage in pagsasanto. For these non-believers, the goal is to express themselves through their "art", even if the practice holds no sanctity for them. As one of the participants explained:

"Kaya lang nila gusto ang mga imahe kasi it is a piece of art. It is not a sacred thing, although pinabasbasan nila kasi they thought it is required kasi nga 'pag Mahal na Araw inilalabas, but other than that, in their perspective, it is an art. Active sila sa simbahan pero, they are just active para sa pagpapaganda ng mga imahe. Other than that, the devotion, it is not there." (The only reason they want an imahe is that because it is a piece of art. It is not a sacred thing, although they have the Church bless it because it is required during Holy Week. Other than that, in their perspective, it is an art. They are active in Church only for the Images.)

However, it is necessary to note that the participants are conscious that there are still limits to the creative freedom to exercise over the divine "Barbies". As one of the participants stated: "...basta hindi extravagant, hindi scandalous ang itsura na para bang nakaball-gown, basta nandun pa rin yung saintly aura nya, pwedeng maging playful ka." (As long as it is not extravagant and not scandalous like being dressed in a ball gown, as long as the image is saintly, you can be playful.)

Legacy. Maintainance of the devotion was also viewed as a legacy. One participant stated that this is a reason for he likes the practice:

"I want to impart something na ite-treasure nila na kumbaga kahit kunwari wala na ako dito sa mundo, kahit papaano ay may naiambag ako na alam ko na pangangalagaan ng pamilya ko. Hopefully, pangalagaan nila". (I want to impart something that they will treasure in case I am no longer around. I have something that my family will treasure.)

However, there was uncertainty on whether younger relatives and friends would be responsive to the idea of inheriting such a responsibility:

"Sakin kasi, wala pa naman akong... yung mga pamangkin ko medyo maliliit pa. Parang hindi ko pa sila nakikitaan ng interes para doon sa mga poon ko. So sabi ko, kung may friends ako na mapag-iiwanan... kung kakayaning sila yung maglabas, edi sa kanila ko ibibigay. Or ibibigay ko na lang sa simbahan." (For me, I do not have nephews and nieces yet. If I have friends whom I can entrust the image and if they can take care of it, then I would give it to them)

Spirituality. Pagsasanto was reported to be a form of contrition. In other words, it is the way of seeking forgiveness for what they believe to be sins or acts of transgressions that they have committed against the will of the divine. What is noteworthy about this theme is the basis of the transgression against the divine that they believe they have committed: 
Interviewer: Sa circle mo ba ng mga santero, mas marami ang bakla na nag-aalaga? (In your circle of santeros, are there many gays?)

"Wala kang makikitang straight. Halos lahat. Siguro sa one hundred percent, may makikita kang mga ano, mga three percent. Straight babae. Straight lalake. Pero ramdam mo pa rin na may bahid" (You will not see straight people. Almost all of them are gay. Over a hundred percent, you will only see three percent who are straight female and straight male, but you can still sense they are not.)

Interviewer: Bakit kaya ganun ang composition ng mga santero? (Why is the composition of santeros like that?)

"Kasi siguro doon namin nakikita yung ano, kasi makasalanan ka na nga eh, diba? Sa nakikita ko kasi... para sa mga beking santero, parang way nila ito ng paghingi ng tawad, ganun."(Probably, we see in being a santero, you know our being sinful? The way I see it, for gay santeros, being a santero is a way to ask for forgiveness.)

The participants' last reason why they like the practice is also for devotion and evangelization, where a more spiritual reason for pagsasanto is realized.: "Habang tumatagal naiisip mo na, ah, kaya pala ako nagsasantero kasi it is for devotion... and for evangelization kasi yun talaga ang purpose ng mga imahe, for evangelization, kaya tayo nagpuprusisyon.." (As times pass, you realize that you became a santero for the devotion and evangelization because that is the purpose of the imahe - for evangelization, that's why we conduct processions.)

The practice of pagsasanto is also reportedly an expression of gratefulness and love to the santo and your religious network - one that is shown by remaining as a santero despite all of its challenges and taking care of the imahe:

"There are some santeros na sa sobrang laking issues, napagod na, nag-give-up na. Pero may iba na lumalaban lang, tulad ko, lumalaban lang ako sa kabila ng issues na binabato sa akin. Ang iniisip ko lang is it is for me to improve kasi nagsanto ka, ang tunay talagang essence ng pagsasanto mo is matuto ka sa Kanya na kumbaga, like si Mama Mary, nagpapakumbaba, ganyan, tapos being faithful sa Diyos, ganun." (There are some santeros with big issues became tired and gave up. But there are others who fight, like me, despite the issues that make up about me. I just think it is for my improvement because you will learn from Him the real essence of being a santero. Like Mama Mary, she became practiced humility and became faithful to God.)

\section{Perceived derived benefits from pagsasanto}

There are also perceived derived rewards from the practice. Forgiveness of sins (plenary indulgence) is part of the religious nature of their practice, and pagsasanto is a devotion that considers benefits as secondary. As one participant puts it, "Syempre sa gagawin mo, hindi kailangan mag-expect ng kapalit. Parang bibigyan ka ng blessings or hindi, ok lang". (You do not have to expect anything in exchange. Regardless if you will receive blessings or not, it is okay). The participants identified personal (health and subsistence and personal development) and social (formation of networks and social standing) rewards as perceived benefits from pagsasanto.

Health and subsistence. The participants believe that God protects them and their respective families from sicknesses and poverty in return for their service. While this does not necessarily mean that they become rich as a result of their devotion, some of the participants opined that this is the reason why they have enough to get by from day to day:

"Hindi kami naghihirap. Hindi kami nakakaranas na maghikahos sa buhay na halos mamalimos ka na. Maubusan man kami ng bigas, may dumarating. Parang blessing na dumadating basta nag-aalaga ka ng imahe". (We do not feel hardships. We do not experience hardships to the point that we will solicit money. If we were to lose rice to eat, rice comes. It is like a blessing coming from taking care of the image.)

Some of the participants, however, noted that other santeros might take advantage of their pagsasanto for more devious reasons:

"May mga nagsosolicit para sa poon pero... hindi nila talaga ginagastos sa imahe nila, ginagawa nilang front yung imahe nila para makapagsolicit, makakuha ng pera para sa sarili nila". (There are those who solicit for the image but they do not spend these for the image. Instead, they use the image as a front to get money for themselves.) 
Personal development. The practice of pagsasanto allowed the santero participants to develop their skills, which provided them an opportunity for personality development.

According to the santero participants, they were able to learn new skills that may be useful in everyday life because these are skills necessary in pagsasanto:

"Well, madami akong natututunan... tulad ng pananahi... yung sa kahoy, kunwari magbabarena, magtuturnilyo... then pag-eelectrician din gawa nung linya ng kuryente, mapag-aaralan mo yung sa wattage kung kakayanin ng generator. And then, sa pagsusuri ng tela-tela, sa pag-aaccessorize, sa pagtingin ng appropriate na alahas." (I learn a lot like sewing, using a grinder, using nails and hammer, fixing electric lines, learning wattage and if the generation can handle it.)

Beyond skills development is the opportunity for personality development - one that may give the santero a more internalized appreciation of their spiritual beliefs:

"I am from a devout Catholic family pero 'pag nakikita mo yung pag-uugali, they are serving yet hindi tugma sa attitude nila. So, in the long run, natutunan ko 'yung pagpapakatotoo. Na kumbaga, nangangalaga ka ng imahe, but that doesn't require na kailangan lagi kang nagdadasal, lagi kang nagsisimba, na you're always active kahit hindi pa panahon ng labas nila. For me, what is important is sa araw-araw ng buhay mo, you make it a point na 'yung naging buhay ng santo, i-apply mo sa sarili mong buhay. Atsaka para maka-impluwesnya ka rin, na makikita sayo ng ibang tao na nag-aalaga ka ng imahe, mabuti kang ehemplo, na sinusubukan mong magpakabuti." (I am from a devout Catholic family, but when you see their behaviors, they are serving, but it does not match their attitudes. So, in the long run, I learn how to be real, like owning an image doesn't require that you always need to pray, go to the church, be active despite it is not the season for the images to be processed. For me, what is important is in your everyday life, you apply the life of the saint. You will influence people, and people will see that you are a good example with owning an image, that you try to be a good person.)

Social rewards. There are social rewards for being a santero, particularly an increase in the number of their friends and acquaintances and a perceived increase in social standing:

"Nung una, isa lang ang kaibigan ko na nagsasanto... then, I started hosting Flickr, and it attracted people. So dun nag-start. Dumami ng dumami, hanggang sa madami na akong kilala. Minsan pa nga, kilala ako, hindi ko sila kilala. Tapos may iba na nagsasabi na inaidolize nila ang imaheng alaga ko, kasi talagang maganda ang gayak." (At first, I only have one santero friend. Then I hosted hosting a Flickr account, which attracted people. It started there. Connections grew until I knew a lot of people. Even sometimes, they know me, but I do not know them. Some say they idolize the image I am taking care of because its decoration is beautiful.)

Beyond forming connections, one participant raised that being a santero can also promote status. As one participant stated, "Feeling ko nakakataas din ng moral yung pag-aalagang imahe. Nakakataas din ng tingin ng tao para sa nag-aalaga ng imahe." (I think taking care of an imahe boosts morale. It makes people to look up to you.) Another participant agrees with this sentiment, claiming that:
"'II my case, oo, may pangalan talaga ako. 'Yung alam na... kapag si [name], ay, hindi papayag yan na basta-basta ang gayak, kailangan bago, kailangan laging may bagong pakulo. So nagigiging kaabang-abang 'yung Imahe mo because of your creativity. Mataas ang tingin sayo ng lipunan kasi may imahe ka, ibig sabihin... ang mga pamilyang may imahe mayayaman talaga. Like our family, mayaman talaga. Noong bata pa ako, 'yung lola ko umuubos ng PhP 100,000.00."(In my case, I have made a name for myself. People know me as someone who takes decorating the Imahe seriously and innovatively. Consequently, people keep an eye out for my Imahe. Society looks up to you because you own an Imahe; they even think that you are affluent if you own one. Like our family, we are really affluent. When I was a child, my grandmother spends Php 100,000.00 for the procession.)

These claims purporting a positive relationship between pagsasanto and social standing seem to be well internalized by some Santeros. One santero, for example, bought a Santo for the main purpose of increasing his social standing in his local community. He reportedly became more known and respected in his local community as a result. It bears noting, however, that not all of our santero participants agree with the benefit of social standing for santeros:

"Ang pagsasanto naman kasi, hindi status symbol yan. Nakapasok kasi yun sa pagigiging 
Catholic... tsaka wala namang point dun: wala namang scores, judge or anything. 'Yun lang, just plain devotion. Sa perspective ko, hindi siya nakakataas. Kasi kung sa pagkakaroon ng imahe ang pagtaas ng posisyon ko sa simbahan, 'di sana lahat ng officers namin sa [religious org] may imahe." (Pagsasanto is not a status symbol. Being a Catholic is anchored on it. Pagsasanto is not graded - no scores, judge, or anything. It is plain devotion. In my perspective, it does not mobilize you. If it does, then religious officers could have owned a religious image.)

\subsection{Discussion}

The results of the study yielded many notable insights about the practice of pagsasanto among gay Santeros. The results suggest that Santero devotion is developed as a result of an early life subjected to intensive integration with religious socialization agents (family, school, and local community) that taught the participants the notion that pagsasantero is normal and a worthy activity to aspire for. The concept of social learning (Bandura, 1971) is particularly noticeable in these narratives - the participants often mentioned older relative Santeros who served as their role model. In some cases, the model is not even a relative but rather a public figure they know of - such as Don Escudero - whom they perceive to be someone worth aspiring to be given the prestige he enjoys as a result of pagsasanto. The salience of this religious network is further felt in the context of gaining access to an imahe - wherewith the Santeros often gain these imahes from religious friends, families, or even the Church itself - and in the act of pagsasanto itself where it has been implied that being a santero is not often an individual activity, but rather a social one that requires the participation of other people who are either hired help or fellow devotees.

It is also worth noting that while the participants were experiencing these early socialization processes into Santero life, they were already in the process of forming their gender identity and experiencing the difficulties of having such a gender identity in a predominantly patriarchal, heteromasculine society. The participants recalled that during their younger days, some of them wanted to play with dolls - a desire they met by borrowing the Barbies of relatives (them having none of their own) or playing with stuffed toys - which, though not necessarily the stereotypical male toy compared to guns, trucks, and action figures, is still not perceived to be as effeminate as dolls. The santero participants were able to negotiate the clash of influences between the religious, social institutions (family, school, and community) surrounding them in their formative years on the one hand, and their gender identity on the other, by becoming a santero. Although they were forbidden to play with dolls in their younger days, they can now do so without fear of social backlash and deterioration of social ties by treating the imahes as dolls. The appeal of these religious images as dolls is ubiquitous enough that even gay non-Catholics, including non-believers, have joined the practice.

The religion-gender dynamic in this practice is further made salient when it came to light that though these openly-gay Santeros see pagsasanto as an opportunity to perform acts often associated with being gay without social backlash, their religious upbringing has internalized in them the concept of gayness as a sin. Being a Santero consequently functions like a middle ground: a venue to be gay and a way to seek contrition for the very same "sinful" gay identity they are manifesting. There may even be merit in surmising that the perception of the imahe as a form of legacy may be partially influenced by the fact that gay Filipinos do not often have families of procreation of their own and, therefore, one of the alternative ways to leave a legacy is through the inanimate religious objects they take care of. In their typologies of legacy, Hunter and Rowles (2005) call this a material legacy, particularly an heirloom which carries history and story within the material to be transferred.

Aside from the religion-gender identity connection, it also became salient how pagsasanto intersects with social status. On the one hand, pagsasanto is related to social status because the practice requires considerable socio-economic capital. Tamayo (2020) reported that, historically, it was the elite families who commissioned processional images in the province because, in addition to their maintenance, ordering and shipping alone are expensive. At present, the narratives of the participants highlighted how resources are needed in the purchase and maintenance of the images. Venida (1996) also noted that the number of imahes processed on Good Friday in Baliwag of Bulacan signified the growing class of affluent families. In later years, the number of images approximately a hundred. Even if the santero does not buy the imahe, the acts of maintaining the imahe, preparing it for religious activities, and fielding it during processions all require substantial monetary sacrifices.

On the other, it is also connected to social status because these socio-economic "investments" are perceived to be rewarded with social acceptance and prestige. In this sense, pagsasanto serves 
as a symbolic gesture of personal accomplishment, and a means to achieve prestige or higher social status within the religious network. Based on acceptance in one's religious in-group, this is further made salient when explained that some of the fellow santeros that they know started with the devotion because it was the trend among gays during their time. In typical Filipino parlance, pagsasantero in this regard has become a method of pakiki-uso or pakikisama to their in-group. As Cheadle and Schwadel (2012) reported, religious similarity fosters social connections. Turner (2001) also reported that religious participation serves as a way for social mobility. There is also an active and growing santero communities on Facebook. Those with more imahes and grander designs for their imahes often enjoy significant fame and clout in the online santero community.

\subsection{Conclusion}

The participants' narratives indicated that the religious family, school, and the community as agents of socialization facilitated their entry to pagsasanto. Access of an Imahe was either through ownership or through entrustment. Regardless of the mode of access, participants reported financial resources and patience as requisites in the practice. Participants reported different reasons for pagsasanto including ego or prestige, conformity to a trend, treatment of imahe as a divine "barbie" for creative self-expression, the aspiration to start a legacy of Pagsasantero in one's family, as an act of contrition, and as devotion and evangelization. Finally, the participants reported subsistence, personal development, and social connections as perceived benefits derived from the practice of pagsasanto.

In exploring the phenomenon, it came to light that the practice is an activity where an individual exercises self-expression via the images in a venue that is mediated by the societal elements of religion, gender, and social status. The participants had different reasons as to why they entered the practice and various personal and social rewards perceived to be derived from it. It may be plausible that the benefits the participants receive from the practice can also be the reasons they entered pagsasanto. This is one limitation of the study that future researchers can explore.

This study is just an initial step in the study of pagsasanto and its reportedly predominantly gay population. However, it is important to contribute to the sociological literature in terms of how persons negotiate the contradictions between a reportedly esteemed religious identity and a deviant gender identity. Future studies in this field of inquiry are encouraged to explore more questions of importance that may branch out from what we have discovered about the phenomenon, such as how Church authorities and its lay members react to these expressions of creativity by gay santeros, how first-generation santeros try to maintain the tradition of pagsasanto in their family especially when they have no personal families of procreation, whether the motivations and experiences of lesbian santeros differ from their gay counterparts, and finally, whether the assumption of this esteemed religious identity ultimately increases the religious, hetero-masculine society's acceptance of gays.

\section{REFERENCES}

Bandura, A. (1971). Social learning theory. New York: General Learning Press.

Berg, B. L. (2001). Qualitative Research Methods for the Social Sciences (4th ed). Needham Heights, MA: Allyn \& Bacon.

Bernard, M. A. (2002). The First Encounter: An Idyll of Innocence. Budhi, 5(3):104-114.

Caulin, V. (2017, November 15). How a Baby Jesus Doll Converted the Philippines to Catholicism. Retrieved October 26, 2020, from Culture Trip website: https://theculturetrip.com/asia/philippines/articles/how-a-baby-jesus-converted-the-philippines-tocatholicism/.

Cheadle, J. E. \& Shwadel, P. (2012). The 'Friendship Dynamics of Religion,' or the 'Religious Dynamics of Friendship'? A Social Network Analysis of Adolescents Who Attend Small Schools. Soc Sci Res, 41(5): 1198-1212. doi: 10.1016/j.ssresearch.2012.03.014.

Creswell, J. W. (2013). Qualitative inquiry and research design: Choosing among five approaches (3rd ed). SAGE Publications, Inc.

Delotavo, A. J. (2001). Images of Christ in Filipino culture and atonement experiences: a case in the contextualization of the gospel message Bibliographic Details. Asian Journal of Theology, 15(1):140-150.

Diocese of San Pablo. (2011). Mga pagdiriwang sa kuwaresma at mga Mahal na Araw. San Pablo City: Komisyon ng Liturhiya, Diocese of San Pablo.

Galang Jr., R. B. (2012). The System of Sponsorship for Processional Images and the Traditions Associated with them in Cabiao, Nueva Ecija, the Philippines. International Journal of Intangible Heritage, 7:46-60.

Hunter, E. G. \& Rowles, G. D. (2005). Leaving a legacy: Toward a typology. Journal of Aging Studies, 19:327-347.

Martin, E., Martin, C. \& Vigne, L. (2011). The importance of ivory in Philippine culture. Pachyderm, 50:56-67.

Peterson, W. (2011). The Ati-Atihan Festival: Dancing with the Santo Niño at the "Filipino Mardi Gras". Asian Theatre Journal, 28(2):505-528.

Peterson, W. (2020). Dancing, marching, and baton twirling with the virgin: Performing community at the Peñafrancia Festival in the Philippines. Australasian Drama Studies, 76:24-76. 
Proclamation No. 809, s. 2005. Retrieved from: https://www.officialgazette.gov.ph/2005/03/15/proclamation-no-809-s-2005/. Tamayo, J. A. L. T. (2020). Contemporary camareros: santos sponsorship in the Philippines today. International Journal of Intangible Heritage, 15: 116-130.

Turner, B. S. (2001). Religious Stratification. In (Smelser, N. J. \& Baltes, P. B. (eds). International Encyclopedia of the Social and Behavioral Sciences. 13136-13139.

Venida, V. S. (1996). The Santo and the Rural Aristocracy. Philippine Studies, 44(4):500-513.

\section{Correspondence:}

SAMUEL BRANDO H. PIAMONTE

sampiamonte@hotmail.com

https://orcid.org/0000-0001-6234-9476

MARK ANTHONY M. QUINTOS

mark.anthony.quintos@dlsu.edu.ph

MINAMI O. IWAYAMA

moiwayama@up.edu.ph 